\title{
An Empirical Analysis of Exchange Rate Pass-Through to Prices in South Africa (2002-2016)
}

\author{
Harris Maduku ${ }^{1}$, Irrshad Kaseeram² \\ Department of Economics, University of Zululand, KwaDlagenzwa, South Africa \\ madhukuharris@gmail.com,KaseeramI@unizulu.ac.za
}

\begin{abstract}
South Africa is currently running inflation targeting monetary policy since the year 2000 solely to achieve price stability. However, the persistent depreciation of the rand is making keeping inflation within the stipulated band very cumbersome. The objective of this paper is to find the duration taken by price indices to respond to exchange rate fluctuations. A Recursive VAR was used to investigate exchange rate passthrough (ERPT) to tradable prices in South Africa. Using monthly data, we find producer prices contributing highly to inflation with an average of $22 \%$ of fluctuations passed to prices. Large and persistent ERPT especially on import and producer prices accompanied by high wage demands and a depreciating currency are worrying factors for South Africa. Policy makers are advised to consider targeting the exchange rate if inflation is to be kept under control.
\end{abstract}

Keywords: Inflation Targeting, Exchange Rate Pass-Through, Recursive, Monetary policy

\section{Introduction}

The monetary policy exchange rate channel is of paramount importance mostly for small and open developing countries like South Africa (South African Reserve Bank, 2002). The country has been hit by a series of rand depreciations mainly after the 2008 financial crisis. Conventional wisdom in monetary economics assumes that persistent currency depreciation makes imports to be costly while exports become more competitive on the international market (Aron et al., 2012b). The South African Reserve Bank (SARB) adopted inflation targeting monetary policy with a sole objective to stabilize prices in the country. However, this objective has been cumbersome to achieve mostly because of a persistently depreciating rand leading to passing through of exchange rate changes to prices assumed to be playing a huge role (Kabundi and Schaling, 2013). The transmission or consideration of the exchange rate changes to prices is defined as Exchange Rate Pass-through (ERPT) depending on the asymmetric behavior of price adjustments (Choudhri and Hakura 2015). Aron et al., (2014a) defined ERPT as the degree to which exchange rate variations influence trade prices and through them to other domestic prices. However, Kabundi and Schaling, (2013) defined it alternatively as the link between nominal effective exchange rate and import prices (first stage) and finally as a link between import prices, producer price inflation and consumer inflation (second stage). Exchange Rate Pass-Through (ERPT) can be divided into two stages, the first stage which is the transmission form exchange rate to import prices and second stage pass through which comes from the import prices to other prices down the pricing chain e. g consumer prices. When imports control a bigger part of the domestic market, the magnitude of exchange rate pass-through is expected to be very high since imports constitute a large portion of the consumption basket.

Knowledge of exchange rate pass-through is very important for a number of reasons. Firstly, the level of ERPT is an approximation of international macroeconomic transmission and thus has implications for the timing of monetary policy intervention (South African Reserve Bank 2004). Hence, the degree and speed of passthrough are important for forecasting inflation and formulating monetary policy responses to inflation shocks (Parsley 2012). In addition, the adoption of inflation targeting demands knowledge of the speed and size of ERPT on inflation. Also, understanding ERPT at the macro and microeconomic levels gives insights into the strength of the international market power of domestic industries vis-à-vis their international counterparts. This objective of this paper is to investigate the speed and size of ERPT in South Africa. The focus will be on both the first stage (exchange rate to import prices) and second stage ERPT (import prices to the producer, export and consumer prices). This paper contributes to the body of knowledge by being the first paper in the context of South Africa to use only the period where the policy has been in place. Also this study is the only study in the South African context to use a Recursive VAR which has the biggest strength in the ordering of variables in the modelling aspect of our variables. A study by Korap, (2007), found the composition of industries in a country's basket to be a kingpin in determining ERPT. He adopted an unrestricted VAR model in examining the effects of exchange rate changes on domestic inflation. 


\section{Literature Review}

This section will do a review of literature specifically from South Africa that was done on the area of research. The studies in question are by Aron et al., (2014a), Edwards and Garlick, (2008), Karoro et al., (2009), Jooste and Jhaveri (2014), Razafimahefa, (2012) and (Parsley, 2012). Aron et al., (2014a) analyzed the inflationary effects of inflation targeting and currency invoicing on import prices in South Africa. Using single equation models and systems to check the pass-through of import price, they discovered that depreciation and volatilities of the exchange rates can increase the options of hedging and foreign currency invoicing because of uncertainties. The moment exporters price their goods in producer currency (foreign currency) there is going to be an increase in the level of pass-through to prices in South Africa, considering the volatilities and depreciation of the exchange rate. Also they found the openness of trade and that of the current account to be culprits in increasing the pass through. Aron et al., (2012) estimated a Johansen Cointegration model and single equations for short-run Exchange Rate Pass-Through (ERPT) using monthly data on import price indices for 1980:1 to 2009:12. They reported an average pass-through of 50\% within a year and $30 \%$ in 6 months. They also found the long-run pass through to be 55\%. The results concur with the general agreement that passes through on import prices is high but depending on the type of goods included in the import basket.

If the bundle has tradable goods that have less pass-through elasticity, then the average estimation will be low. Edwards and Lawrence, (2006) focused on an analysis of trade flows and exchange rate pass-through in South Africa based on the relationship between the nominal effective exchange rate (NEER) and trade flows; they also used a Johansen cointegration approach. Their empirical evidence supports the positive relationship between the balance of trade and real depreciation of the rand. This means that import or trade prices respond to changes in the exchange rate. After they used quarterly data from 1980 to 2005, they found that pass through to export prices had an estimation of 0.85 (85\%) and that of import prices was at 0.89 (89\%). Karoro et al., (2009) investigated the long-run pass-through in South Africa, employing the VECM. They checked the equilibrium pass through using the Johansen technique it was based on a VAR including two lags but they seemed very short of monthly data. They used various proxies for the exporter's costs of production and that resulted in long-run pass-through measurements that varied in the range of $0.75(75 \%)$ to $0.82(82 \%)$. Their findings of the equilibrium pass-through to import prices appeared to be higher for depreciation, $0.72(72 \%)$ than that of appreciations $0.64(64 \%)$.

They also found no significant asymmetry in the ERPT of large or small changes in the exchange rate. One of the recent studies was done by Jooste and Jhaveri, (2014) using a time-varying VAR as they investigated the effects of time-varying ERPT in South Africa. The methodological approach adopted in the study made use of the monthly import, export and consumer prices in South Africa from 1980 to 2011. Their results showed that, pass through is higher in the first period of the year than later but the long-term pass through is always higher than the short term. Export pass-through in the first period was $6 \%$ and $7 \%$ in the $12^{\text {th }}$ period, while the import pass-through was $3 \%$ in the first period and $7 \%$ in the $12^{\text {th }}$ period. This concurs with research by Parsley, (2012) who also concluded that long-run pass-through is higher than the short-run one. Parsley, (2012) estimated the effects of exchange rate changes to import prices and services in South Africa using panel data of goods and services at the dock and using disaggregated homogenous import units. This study found a low pass through to the final consumer goods prices of between $14 \%-27 \%$ in two years after an exchange rate change.

There was an unusual phenomenon as it was found from this research that pass through of services is higher than that of goods. Under normal circumstances, services are domestic-oriented and hence are not much affected by exchange rate changes. This study attributed the decline in pass-through to changes in the consumption baskets of people, including more goods which are not affected by the exchange rate changes, and therefore with low ERPT; the researcher saw the decrease as not linked to changes in the monetary environment or pricing behavior of the firms. The study concurred with the idea that, exchange rate shocks affect domestic inflation in a specific manner and one which is estimated to be from the manufacturer's price down to the level of the consumer. He also concluded that countries with the fixed exchange rate and lower tariffs realize higher long-run ERPT to import prices than domestic prices as compared to those countries 
with high tariffs and floating exchange rates like South Africa. Razafimahefa, (2012) checked on the asymmetries of the pass-through in South Africa using exchange rate data.

\section{Methodology and Data Issues}

Variables Description and Data Issues: The empirical work will use monthly data for a Recursive VAR as outlined by Ouliaris et al., (2016) who argue that SVAR is better specified using disaggregated data. The period captured in this research is motivated by the need to check the contribution of exchange rate changes within the period of the inflation targeting regime and by so doing it will cover the year 2002 January up to 2015 December. The primary source of the data is Quantec, a data house that gathers data from all over the world and makes it available to researchers at a cost. This makes the data more reliable since it comes from a recognized source. Below is a list of variables to be used in the model. He investigated the effects of the rand depreciation for 4 quarters and 8 quarters. Using the sign restricted VAR, he found that, pass through is less asymmetric after 4 quarters (13\%) than after 8 quarters (16\%). This means that prices respond more to depreciation than an appreciation but the level of response also depends on the size of the depreciation. If it is high, then exporters may choose to put markups on their prices but if it is small they may choose to just absorb the change so that they will protect their market share. It also depends on the level of completion and availability menu costs or costs of changing prices.

Output Gap: The output gap is the difference between the potential output of South Africa and the actual output produced in a given year. Petrol Prices: Petrol prices will be entered into the model representing the world oil price shocks. The oil prices represent the supply shocks in the model. NEER: Is the nominal effective exchange rate which is a proxy for the exchange rate. IMP: The import price index is used as a proxy to represent the prices of the goods and services imported by the country. PPI: Is the producer price index which is the average weighted value of the index of the goods and services produced for domestic use or international market consumption excluding the imports. Expo: Is the export price index of South Africa for goods and services produced in South Africa and sold in other countries. CPI: Is the consumer price index of South Africa representing a basket of goods and services sold to the consumers in South Africa.

Recursive VAR Approach: The recursive VAR framework on ERPT was borrowed from the work of McCarthy, (2000). The assumption of the estimation is that of a recursive ordering of the variables in which the international supply shocks in this case represented by petrol prices and demand shocks represented by the output gap enter the model first to affect all the other variables in the model without them being affected by any other variable in the model. The supply and demand shocks are exogenous to the exchange rate in period $t$. These exogenous variables to the exchange rate are determined in each period by the expectations of the previous period and an error. So in the ordering of say, Petrol prices, output gap and exchange rate, then we would exclude the contemporaneous values of the output gap and exchange rate from the equation of petrol prices. Exclude the contemporaneous value of the exchange rate from the equation of the output gap exclude no variable and meaning that we include petrol prices and the output gap in the equation of exchange rate.

The model has 7 variables and they are ordered in a way that the consumer prices will be affected by all the other variables in the model without it affecting any variable and that it is guided by the fact that the CPI is more of like inflation itself so we cannot allow it to affect any variable in the model.

$\pi_{\mathrm{t}^{\mathrm{petr}}}{ }_{t-1}^{E}\left(\pi_{\mathrm{t}}^{\mathrm{petr}}\right)+\varepsilon_{\mathrm{t}^{\mathrm{petr}}}$

$Y_{t}={ }_{t-1}^{E}\left(Y_{t}\right)+\mathrm{a}_{1} \varepsilon_{\mathrm{t}^{\mathrm{petr}}}+\varepsilon_{t}^{y}$

$\Delta e_{\mathrm{t}=t-1}^{E}(\Delta e)+\mathrm{b}_{1} \varepsilon_{\mathrm{t}^{\mathrm{p}}} \mathrm{p}^{\mathrm{pet}}+\mathrm{b}_{2} \varepsilon_{\mathrm{t}}^{\mathrm{y}}+\varepsilon_{t}^{\Delta e}$

Where PETR is the world oil prices (international supply shock) to South Africa since which is a small open economy and a price taker. This shock can be inflationary if the oil prices go up and deflationary when it goes down, $\mathrm{Y}_{\mathrm{t}}$ measures the output gap in the country and will be measured using the difference between actual output and potential output, $\Delta e_{\mathrm{t}}$ is the change in the exchange rate and $\varepsilon_{\mathrm{t}}$ are the respective shocks which occur at each stage. This exchange rate shock feeds into domestic inflation through the finished imported product or imported inputs by the manufacturers and then passed through to the producers and later to export and consumer prices. 
$\pi_{t}^{i m p}={ }_{t-1}^{E}\left(\pi_{t}^{i m p}\right)+\mathrm{c}_{1} \varepsilon_{t}^{p e t r}+\mathrm{c}_{2} \varepsilon_{t}^{y}+\mathrm{c}_{3} \varepsilon_{t}^{\Delta e}+\varepsilon_{t}^{i m p}$

$\pi_{t}^{p p i}={ }_{t-1}^{E}\left(\pi_{t}^{p p i}\right)+\mathrm{d}_{1} \varepsilon_{t}^{p e t r}+\mathrm{d}_{2} \varepsilon_{t}^{y}+\mathrm{d}_{3} \varepsilon_{t}^{\Delta e}+\mathrm{d}_{4} \varepsilon_{t}^{i m p}+\varepsilon_{t}^{p p i}$

$\pi_{t}^{c p i}={ }_{t-1}^{E}\left(\pi_{t}^{c p i}\right)+\mathrm{e}_{1} \varepsilon_{t}^{p e t r}+\mathrm{e}_{2} \varepsilon_{t}^{y}+\mathrm{e}_{3} \varepsilon_{t}^{A e}+\mathrm{e}_{4} \varepsilon_{t}^{i m p}+\mathrm{e}_{5} \varepsilon_{t}^{p p i}+\varepsilon_{t}^{c p i}$

$\pi_{t}^{\text {exp }}={ }_{t-1}^{E}\left(\pi_{t}^{\text {exp }}\right)+f_{1} \varepsilon_{t}^{\text {petr }}+f_{2} \varepsilon_{t}^{y}+f_{3} \varepsilon_{t}^{\Delta e}+f_{4} \varepsilon_{t}^{i m p}+f_{5} \varepsilon_{t}^{p p i}+f_{6} \varepsilon_{t}^{c p i}+\varepsilon_{t}^{\exp }$

Other variables are: imp which is the import prices represented by the import price index for South Africa; PPI- producer price index for the national producers; EXP- the export price index for goods exported by South Africa into the world market, these goods become cheap when the currency is depreciating and cheap under the periods of depreciation and finally the CPI- the consumer price index in the country formed by a basket of goods and services representing all the goods and services consumed by South Africans.

Estimation Procedure: Any type of VAR starts with a reduced form VAR and after the traditional VAR has been run all other restrictions on the model can be done. The variables in the model are arranged in the following order: (Petrol prices, output gap, exchange rate, import prices, producer prices, export prices, consumer prices) starting with a structural representation of linear dynamic equations of the following form: $A_{0} X_{t}=A(L) X_{t-1}+B \varepsilon_{t}$

In this case $X_{t}$ will be the $\mathrm{p}(=7)$ - dimensional set vector housing the variables being used in the model, $A_{0}$ gives a description of the contemporaneous relationships amongst the variables in the model, $A(L)$ is the finite-order matrix polynomial in the lag operator $L$ and lastly $\varepsilon_{t}$ is a vector of structural disturbances that can be interpreted and it is drawn from the list of equations spelling out the system with covariance matrix and the equations are those above showing the recursive structure of the model. Under lenient conditions $\left(\mathrm{A}_{0}\right.$ invertible), we can also show the $\mathrm{p}$-dimensional Vector $\mathrm{X}_{\mathrm{t}}$ in the following reduced form presentation:

$X_{t}=A_{0}^{-1} A(L) X_{t-1}+e_{t}$

In this case the VAR residual vector $e_{t}=A_{0}^{-1} B e_{t}$ is n.i.i.d. with full variance-covariance (VCV) matrix. After the above structural form equation, then we will be able to derive the relationship between the VCV matrices (unobserved) $\varepsilon_{t}$ and $e_{t}$ (observed):

$E\left(e_{t} e_{t}^{\prime}\right)=A_{0}^{-1} B E\left(\varepsilon_{t} \varepsilon_{t}^{\prime}\right) B^{\prime} A^{-1}$

In this case it then holds that $\widehat{\sum} \mathrm{e}=\hat{A}_{0}{ }^{-1} \widehat{B} \mid \hat{B}^{\prime} \hat{A}_{0^{-1}}$. The identification demands the restrictions to be done on $\mathrm{A}$ and B. This ordering of the variables is best known as the Cholesky decomposition proposed by Sims, (1980), and it is the one also followed by McCarthy, (2000), Bonato and Billmeier, (2002) and others. On the issue of identification, the study used the $A B$ model proposed by (Amisano and Giannini, 1997). As iterated previously, identification is the problem of interpreting the correlations in a model in a causal manner and that problem cannot be solved by a model itself by theoretical restrictions on the model. The number of restrictions in the model is determined by the difference between the known and unknown parameters in the model. In general terms the number of restrictions for our exact identification is $2 n^{2}-n(n+1) / 2$ on A and B matrices. On the AB model adopted from Amisano and Giannini, (1997), the B matrix is just there to identify structural shocks to the model.

In short it is called the identification matrix. The non-zero elements in the identification matrix (B) would then allow the structural shocks to affect more than a single variable in the model. By so doing the shocks will affect each and every variable in the model. Under this framework since the matrix B is the identification matrix and it has non-zero off-diagonal elements then matrix $A$ is assumed to be lower triangular. In this scheme, the identification of shocks will depend on the variable ordering and in this context our recursive ordering of the variable is what will determine the identification of structural shocks in the model. Since all the variables are assumed to be endogenous under the VAR framework, the degree of endogeneity when the variables are ordered recursively rises along the variable ordering:

$$
A=\left(\begin{array}{cccc}
1 & 0 & \cdots & 0 \\
a_{21} & 1 & & \\
\vdots & & \ddots & \vdots \\
a_{n 1} & a_{n 2} & \cdots & 1
\end{array}\right), B=\left(\begin{array}{cccc}
b_{11} & & \cdots & 0 \\
0 & b_{22} & & 0 \\
\vdots & & \ddots & 0 \\
0 & 0 & 0 & b_{n n}
\end{array}\right)
$$


In the VAR modelling, the contemporaneous correlations of the variables are then reflected in the crossequation residual correlation. After restrictions are done of the matrix A and B then the Cholesky factorization is done to so that is sets to zero all the residual correlations amongst the variables in the model prior to causal ordering. Once the required and necessary restrictions to the model are done then a number of exercises can then be done like the impulse response functions and variance decompositions.

\section{Data Issues}

Unit Root Tests: The study uses time series data and the data was tested for stationary in their levels. Using the ADF and Phillips-Peron, we find that all our variables are non-stationary in their levels and they become stationary after first difference I (1). This conforms to the VAR requirements that all the variables should be integrated of the same order. The study did not go on to test for cointegration since the objective of the paper was not interested in knowing the long-run relationship of the variables but the duration is taken by the variables to respond to a shock of exchange rate prices and import prices. However, we went on to check for the lag length using the Schwarz Information Criterion (AIC) and the model chose 3 lags to be used by a system of equations in the Recursive VAR. For model stability we computed the Inverse Roots of AR Characteristic Polynomial and it confirmed that the model is stable we proceeded with estimation of main results.

Table 1

\begin{tabular}{llllll}
\hline Variable & ADF & \multicolumn{3}{l}{ Phillips-Perron } & I(d) \\
\hline & Level & $1^{\text {st }}$ Diff & Level & $1^{\text {st }}$ Diff & I(1) \\
Gap & -0326162 & -4.227060 & -0.062317 & -12.11775 & I(1) \\
CPI & 0.346201 & -10.27714 & 0.074533 & -10.93125 & I(1) \\
PPI & -0.906680 & -6.992048 & -1.214282 & -12.21109 & I(1) \\
Imp & 0.402233 & -11.12141 & 0.077252 & -11.24372 & I(1) \\
PTR & -1.224015 & -9.539517 & -1.147970 & -8.466560 & I(1) \\
NER & -1.171132 & -3.117750 & -0.604433 & -4.016799 & I(1) \\
Exp01 & -1.060832 & -12.46426 & -1.115891 & -12.48133 & I(1) \\
\hline
\end{tabular}

\section{Research Findings and Discussion}

Impulse Response Functions (Recursive VAR): Impulse responses identify the responsiveness of the endogenous variables in the VAR when a shock is put to the error term such as $u 1$ and $u 2$ on the equations in the system (Ngalawa, 2009). A unit shock of the exchange rate is applied to each of the above-mentioned variables to see its effect on the VAR system. According to McCarthy (2000), in the calculations of the impulse response functions, ordering of the variables is important and this study has adopted the Cholesky degrees of freedom that are adjusted in E views 9.5.

Figures: Response of Other Price Variables to an Exchange Rate Shock
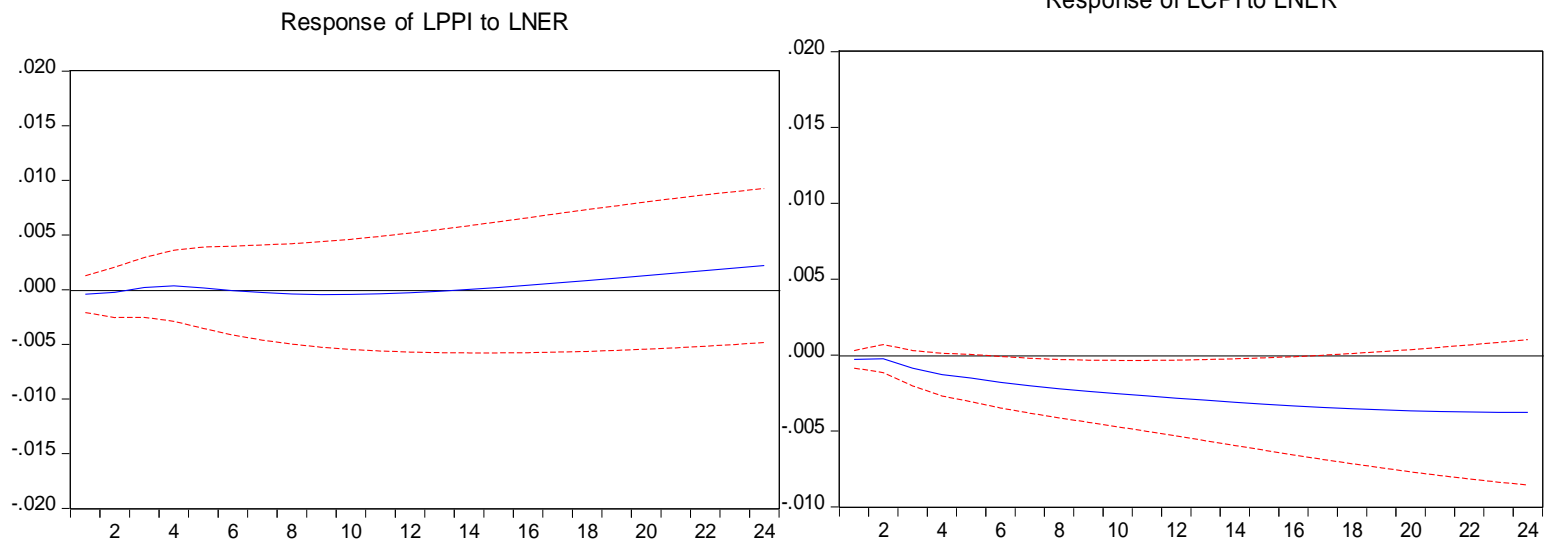
Response of LEXPO1 to LNER

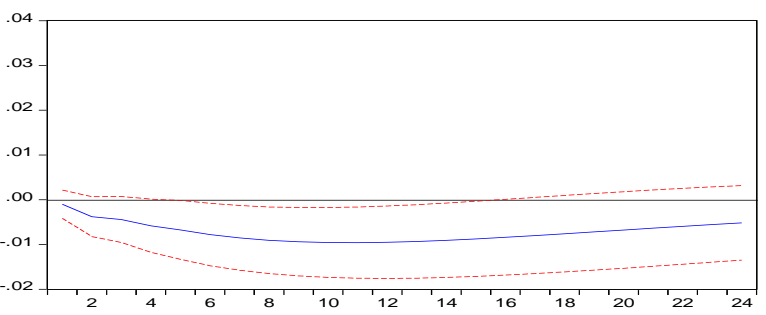

An unexpected shock in the exchange rate corresponding to an unanticipated 1 percent change in the exchange rate is not immediately felt by the import prices in the South African economy. The shock is mostly felt between 4 to 6 months then its impact becomes less and less as time goes by. This means that the import prices respond to exchange rate changes with a lag. Import prices respond positively after a shock in the petrol prices also showing no immediate response. The petrol price shock is mostly felt by the import prices between 2 to 4 months then its impact goes down with time. There is an immediate negative response in the import prices as a result of an unexpected shock in the output gap between 0 to 2 months. In the fourth month is when the import prices respond positively to a shock in the petrol prices. Import prices respond positively at an increasing rate from the $10^{\text {th }}$ month onwards. The impact of an unexpected import price shock down the pricing chain is immediately felt by the producer prices and the export prices with the impact fading away after 2 years in the export prices. This means that prices are easy adjusting upwards than downwards. Producer prices show a constant negative response with the shock felt considerably after one year but then the impact goes down with time at a constant rate. Consumer prices respond sluggishly to a shock in the VAR coming from the import prices. The shock will increasingly be felt in the consumer prices after a year (12 months) as it goes on increasing with time.

Variance Decompositions: The fluctuations in import prices are largely accounted for by own shocks of the cause but shocks to the exchange rate account for the highest percentage fluctuations in the import prices. After a shock to the exchange rate, the import prices respond by $17.27 \%$ after only 6 months. The effect of a shock into the exchange rate will increase the fluctuations in the import prices to $27.54 \%$ after one year. These results confirm or agree with the findings from studies by Parsley (2010) and (Aron et al., 2014). They found that the import prices were being accounted for by the exchange rate by the same magnitude. The effect of a shock to exchange rate on prices will increase as time goes by but at a decreasing rate after one year. This can be observed by a steady increase in the fluctuations from 15 months to 21 months since the fluctuations increased from $29.66 \%$ to $31.27 \%$ respectively. After 24 months the shock to the exchange rate will contribute to a $31.30 \%$ fluctuation in the import prices. This then means that the effect increases with time and its effect will be felt mostly after 2 years with half of the effects experienced 6 months after the shock has taken place.

A shock to import prices accounts for $31.47 \%$ fluctuations in the producer prices only one month after the shock meaning that the producer prices in South Africa quickly respond to changes in the import prices. However, although the effects are immediate, they decrease at almost a decreasing rate as time increases up to one year before it starts to increase again. It should be a worrying factor for the monetary policymakers because the arguments in the literature suggest that pass-through decreases with time but from the look of these results ERPT is not decreasing meaning to say that it will continue to cause more pressure on the average inflation figures. Petrol prices are not spared since they account for quite significant fluctuations in the import prices. A shock to the petrol prices leads to a $7.24 \%$ change in import prices after only 1 month meaning that the shock to import prices is immediately felt in the South African economy because the percentage is quite big and very significant. The fluctuations will then increase by more than $100 \%$ after 6 months increasing from $7.24 \%$ to $17.98 \%$ after only 3 months. The fluctuations after a shock to the petrol prices are immediate and they are quickly influential on the prices the South African importers pay.

This is basically because petrol or oil prices are one of the main production and operation costs that are immediately felt by any producer and that will force producers to quickly adjust their prices to remain making profits in business. However, the effect will be increasing at a decreasing rate over 6 months, 12 months, 18 months and finally 24 months $(17.94 \%, 19.96 \%, 21.27 \%$ and $21.59 \%$ respectively). This is 
observed by a decrease in the fluctuations in the producer by $23.94 \%$ after 3 months down from $31.47 \%$ after one month. After 6 months the shock in the import prices will account for $19.78 \%$ changes in the producer prices down from $23.94 \%$. After one year the impact of the import price shock will account for $20.45 \%$, after 18 months 21.64 and $21.09 \%$ meaning that the effect increased from 12 months up to 18 months although at a constant rate. After 24 months the effect starts to increase as well. The producer prices were assumed to be a big contributor to the changes in export prices but from the results import prices are contributing the most. Unexpected shocks in the Producer prices account for $3.05 \%$ after a month but the impact goes down to $1.34 \%$ after six months before it goes further down to $0.73 \%$ in 12 months' time and $0.58 \%$ after 2 years.

Although the effect of the shock as if it is immediately felt in the export prices it is its magnitude which is a worrying factor but the reason could be the fact that producer prices have not been changing much because of the low commodity demand on the world market and the adjustment of the prices especially for a small economy like South Africa not being easy to adjust. It is within the researcher's expectations to see that all the variables in the model are contributing to the fluctuations in the consumer prices. Since the model used a recursive approach, all the variables in the model have an effect without them being affected much by the fluctuations of the consumer prices. Direct ERPT is significant for consumer price increases as time elapses as can be observed from table 5.5.7 above. As a result of an unexpected shock in the exchange rate, the consumer prices respond by $0.51 \%$ after one month before they fluctuate by $1.36 \%$ after 3 months. The exchange rate accounts for a $5.49 \%$ fluctuation in the consumer prices after 6 months then by $11.55 \%$ after a period of 12 months (1 year). It can be observed that the effect of the shock increases as time increases. In the $24^{\text {th }}$ month, the fluctuations in the consumer prices as a result of a shock to the exchange rate rise by $13.25 \%$.

This confirms previous work of previous researchers on South Africa as they have also seen the effects of exchange rate changes to consumer prices at around the same range for example Razafimahefa, (2012), Rigobon, (2007) and Aron,et al. (2014) who found ERPT to CPI as 12\%, 13\% and 10\% respectively. On the consumer prices the producer prices were expected to have made a mark but from the look of things the producer prices have got a paltry effect of $0.21 \%$ after one year, $0.89 \%$ after six months, $0.63 \%$ in the period up to one year and only an increase to $1.29 \%$ after two years. The assumption behind this is either that the producer prices take time to have an effect in the consumer prices or either the prices are sticky in South Africa especially after the changes in the exchange rate. There is quite a lot of competition amongst the local producers in South African and goods that are coming from abroad. The need for survival in the case of local producers is what might make the prices sticky and not being passed on much to the consumer prices which means that the consumer and export prices are being shaped by other variables in and outside this model.

\section{Conclusion and Policy Recommendations}

The objective of this paper was to see the duration is taken and magnitude of response by tradable prices in South Africa in response to an exchange rate shock. We find producer prices highly responding to an exchange rate shock more than other tradable prices with a $22 \%$ response after an exchange rate shock. The pressure from the depreciating rand on prices is facilitating a significant contribution to the average inflation in the country. This is witnessed by the inflation rates that have been always on the neck of the upper band and sometimes going outside the 6\% upper band especially the 2015/2016 period. Findings from this lead us to advise that monetary policy authorities in South Africa need to keep track the contribution of the exchange rate volatilities on prices. Although the Inflation targeting frameworks succeeded during the early years from its inception, the past 3 years have seen monthly inflation in the upper band and sometimes outside the stipulated band. This means that targeting inflation is getting cumbersome since the target is sometimes missed. In the event that the current situation persists the following suggestions should be considered by the policymakers. The Reserve Bank should start to consider extending its objectives from solely price stability but also to exchange rate stability since it is evident that targeting inflation only is grappling save to the South African situation. This is evident by moderately high Exchange rate pass-through to import and producer prices. If the Reserve Bank could adopt a managed float, that could help to stabilize the exchange rate then prices since it is evident enough that exchange rate changes are contributing highly to inflation. 


\section{References}

Amisano, G. \& Giannini, C. (1997). Topics in Structural VAR Economics. Berlin: Springer.

Aron, J., et al. (2014(a). Exchange rate pass-through to import prices, and monetary policy in South Africa. Journal of Development Studies, 50(1), 144-164.

Aron, J., et al. (2012(b). Exchange rate pass-through in developing and emerging markets: A survey of conceptual, methodological and policy issues, and selected empirical findings. Journal of Development Studies, 50(1), 101-143.

Bonato, M. L. \& Billmeier, M. A. (2002). Exchange rate pass-through and monetary policy in Croatia, International Monetary Fund.

Choudhri, E. U. \& Hakura, D. S. (2015). The exchange rate pass-through to import and export prices: The role of nominal rigidities and currency choice. Journal of International Money and Finance, 51, 1-25.

Edwards, L. \& Lawrence, R. Z. (2006). South African Trade Policy Matters: Trade Performance and Trade Policy. NBER Working Paper Series No. 12760.

Edwards, L. \& Garlick R, (2008). Trade flows and the exchange rate in South Africa. ,"CID Working Papers 135, Center for International Development at Harvard University.

Jooste, C. \& Jhaveri, Y. (2014). The Determinants of Time-Varying Exchange Rate Pass-Through in South Africa. South African Journal of Economics, 82(4), 603-615.

Kabundi, A. \& Schaling, E. (2013). Inflation and inflation expectations in South Africa: an attempt at explanation. South African Journal of Economics, 81(3), 346-355.

Karoro, T. D., et al. (2009). Exchange rate pass-through to import prices in South Africa: is there asymmetry? 1. South African Journal of Economics, 77(3), 380-398.

Korap, L. (2007). Impact of exchange rate changes on domestic inflation: The Turkish experience. Journal of Development Economics, 14(2), 34-60.

McCarthy, J. (2000). Pass-through of exchange rates and import prices to domestic inflation in some industrialized economies. FRB of New York Staff Report, (111).

Ngalawa, H. P. (2009). Paper presented at the 14th Annual Conference of the African Econometric Society, 810 July 2009, Dynamic effects of monetary policy shocks in Malawi, Abuja, Nigeria.

Ouliaris, S., et al. (2016). Quantitative Macroeconomic Modeling with Structural Vector Auto regressions-An E Views Implementation.

Parsley, D. C. (2012). Exchange rate pass-through in South Africa: Panel evidence from individual goods and services. Journal of Development Studies, 48(7), 832-846.

Razafimahefa, I. F. (2012). Exchange rate pass-through in Sub-Saharan African economies and its determinants.

Rigobon, R. (2007). Through the Pass-Through: Measuring Central Bank Credibility. CID Working Paper No. 143, Center for International Development, Harvard University, 1.

Sims, C. A. (1980). Macroeconomics and reality Econometrica: Journal of the Econometric Society, 1-48.

South African Reserve Bank. (2002). Exchange Rate Pass-Through and South African Import Prices, SARB Working Paper WP/02/03. Pretoria: South Africa.

South African Reserve Bank. (2004). Experience of Inflation targeting in S. A. SARB Quarterly Bulletin, 242, S103. 